\title{
DEVELOPMENT OF WAQF IN INDONESIA: THE SWOT ANALYSIS OF INDONESIA WAQF BOARD (BWI)
}

\author{
Prof. Dr. Mohamed Aslam Mohamed Haneef ${ }^{1}$ \\ Dr. Nazrol Kamil Bin Mustaffa Kamil ${ }^{2}$ \\ Qurroh Ayuniyyah $^{3}$
}

\begin{abstract}
Purpose - As the most Moslem populous country, Indonesia has a great potential in waqf assets and fund. The House of the Representatives has regulated Waqf Act No. 41/2004 as of 27 October 2004 to support the development of waqf in the country. Indonesia Waqf Board (abbreviated as BWI) was established by the President of the Republic of Indonesia as the implementation of this Act. The role is to become coordinating institution of existing nazhir (waqf managers) in managing and supervising waqf assets and fund.

This paper aims to evaluate waqf management conducted by BWI. The paper also identifies the issues of waqf management in Indonesia by using SWOT (strengths, weaknesses, opportunities, and threats) analysis.

Design/Methodology/Approach - The study employs both primary and secondary sources. The primary data is through the interview with the Vice Chairman of BWI, while secondary sources are through published regulation and reports, journal papers, and articles.

Findings - Since its establishment, BWI has faced several strengths, weaknesses, opportunities, and weaknesses. The strengths include an independent status of BWI and good cooperation with other interrelated institutions.

With regard to its weakness, the dualism between BWI and Waqf Directorate of Ministry of Religious Affair has been becoming further internal challenge for the Board. Moreover, lack of integration between BWI and other waqf institutions has also hampered BWI to achieve its objectives.

The opportunities are the high Moslem population in Indonesia and great potential of waqf cash and land. On the other hand, the threats comprise lack of awareness and knowledge of the Moslem in Indonesia. Besides, the biggest threat occurs on the capacity of waqf managers (nazhir). Meanwhile, waqf land status, change in waqf land location, and controversy of cash waqf are considered as the other threats.

Originality/value - This study is expected to provide the current condition in waqf management and its lesson learnt for the development of waqf in Indonesia, specifically, as well as in other countries, generally.
\end{abstract}

Keywords Waqf, Management, SWOT Analys is

\footnotetext{
${ }^{1}$ Professor at Department of Economics, Kulliyyah of Economics and Management Sciences, International Islamic University Malaysia, mdaslam@iium.edu.my

${ }^{2}$ Assistant Professor at Department of Finance, Kulliyyah of Economics and Management Sciences, International Islamic University Malaysia, nazrol@ iium.edu.my

${ }^{3} \mathrm{Ph}$.D Candidate at Department of Economics, Kulliyyah of Economics and Management Sciences, International Islamic University Malaysia, ayuniyyah@gmail.com
} 
Paper type General review

\section{Introduction}

Islamic economics has been growing immensely for roughly four decades since the First International Conference on Islamic Economics held in Makkah in February 1976. There are many prospective instruments in the discipline that play important role in achieving the betterment of people's life by attaining the ability to fulfill basic needs, rising standard of living, alleviating poverty, and creating brotherhood among Moslem. One of these instruments that need to be developed due to its huge potential is waqf.

According to Kahf (2002), waqf is "... holding certain property and preserving it for the confined benefit of philanthropy and prohibiting any use or disposition of it outside its specific objective". The concept of waqf has been recognized a very long time ago since the Ka'bah was built as worship center for people (Kahf, 2002).

Accordingly, the highlight of waqf idea is the perpetuity requirement of its capital, thus majority of waqf assets are in form of real assets like lands. Not only for the religious purposes, waqf lands have been used also for the education sector development. Al-Azhar University in Egypt, University of Cordova in Spain and Universitas Islam Indonesia in Jogjakarta, Indonesia are some instances of educational institutions that were originated and supported using waqf lands (Zaki et al, 2008).

However, as the waqf concept has developed over periods, financial assets are also possible for waqf purpose. As long as the principal is preserved, money, for example, can also be used as waqf assets. This idea has been practiced since the second century of Hijriyah, when a prominent Islamic scholar namely Imam az Zuhri advised dinar and dirham waqf for the purpose of religious and social development and education. Moreover, in Turkey, the word 'cash waqf' has been familiar among the society since fifteenth century ${ }^{4}$.

In Indonesia, the attention towards waqf development was still limited. This is indicated by the slow progress of waqf institutions in the last decade, which results minimum research and literature on waqf as compared to other area such as Islamic banking and zakat (Ihsan and Adnan, 2010).

However, due to its great potential, there has been good intention from the government to develop waqf since the launch of Waqf Act No. 41/2004 that administers national waqf management. As the continuation of this Act, Badan Waqf Indonesia (BWI) was then established three years after, as the independent coordinating and supervising institution of waqf management for the national and international level.

In coherence with other private waqf managers such as Dompet Dhuafa, BWI has attempted to progress waqf development with the desire to optimize waqf asset in

\footnotetext{
${ }^{4}$ Retrieved from http//bwi.or.id/index.php/in/wakaf-uang-tentang-wakaf-57
} 
order to give better impact for the society. During the process, BWI has faced up and down sides in improving waqf potential in order to achieve its objectives. Therefore, the main purposes of this paper are to perform waqf management done by BWI and identify some unique issues by using SWOT (strengths, weaknesses, opportunities, and threats) analysis.

The paper comprises seven sections including introduction as the first one. The second section is literature review followed by methodology in the third section. Section four discusses the profile of Badan Waqf Indonesia (BWI), includes its brief history, vision and mission, and duties and authorities. Section five presents the potential and realization of waqf assets and fund in Indonesia. The following section deliberates some unique issues faced by BWI by using SWOT (strength, weakness, opportunities, and threat) analysis. Last section concludes the paper and presents some recommendations.

\section{Literature Review}

According to Kahf (2002), literally waqf means hold, confinement or prohibition. As mentioned earlier, the term waqf in Islamic economics is defined as "...holding certain property and preserving it for the confined benefit of philanthropy and prohibiting any use or disposition of it outside its specific objec tive". Hence, waqf has two major features namely perpetuity and permanence of stipulations of waqf founder.

Kahf (2002) classifies waqf into three types. Firstly, religious waqf, which comprises mosques and real estates to provide revenue for mosques' maintenances and expenses. Secondly, philanthropic waqf that targets in helping poor people in the society as well as providing public facilities. Thirdly, posterity or family waqf, which restricts to be given for one's own family and descendants.

In Indonesia, the theoretical concept of waqf is generally presented in Waqf Act No 41/2004. Accordingly, the function of waqf aims to realize economic potential and benefit of waqf assets for the purposes of worship, religious activities and prosperity. There are six elements of waqf namely wakif ${ }^{5}$, nazhir ${ }^{6}$, waqf assets, waqf pledge, waqf assets allocation, and waqf period. The assets of waqf can be in the form of real assets (lands, building, etc.) as well as financial assets (money, gold, etc.).

With regard to cash waqf, Badan Waqf Indonesia Regulation No 1/2009 clause 1.3 defines the term as waqf in the form of money (cash) that can be managed into productive sector which return is disbursed to maufuq alaih ${ }^{7}$. The return of cash waqf is used for social development, education, religious activities, and health sectors.

\footnotetext{
${ }^{5}$ Wakif means waqf donator or legal owner of waqf assets, which can be individual, organization or corporation.

${ }^{6}$ Nazhir means waqf manager, which can be individual, organization or corporation. It is sometimes called as Mutawalli. Both terms are used interchangeably.

${ }^{7}$ Maufuqalaih means waqf return beneficiary.
} 
Rashid (2014) studies about factors affecting the development and good governance of waqf. Accordingly, there are four global problems influencing waqf, include the fraudulent behavior of waqf managers, the absence of long-term planning on waqf development, the lack of survey on waqf, and the government inclusion that creates power misuse and bureaucratic ineffectiveness. The study suggests organizing a conference on Global Waqf Management in order to discuss common problem faced by waqf management over the world.

Ihsan (2007) analyzes accounting and management practice of two waqf institutions namely Dompet Dhuafa, as cash waqf administer, and UII Waqf Foundation, as land waqf manager. The study shows that Dompet Dhuafa presents a more publicly transparent and accountable report than UII Waqf Foundation does. In terms of waqf management, Dompet Dhuafa has a special division namely Tabung Waqf Indonesia (TWI) or Indonesian Waqf Deposit that administers the fund. They distribute the fund into two main programs include social and investment activities. The former provides free facilities such as health center and Islamic school, while the latter is allocated into various investment channels like baitul mal, trading and farming. As for UII Waqf Foundation, a waqf office takes over the management and majority of waqf asset is used for the educational purposes.

By taking case study of Indonesian Waqf Deposit (IWD), Affandi and Nufus (2010) examine its cash revenue, cash allocation on productive sector and cash return. Moreover, the research assesses the effectiveness of cash waqf allocation policy. The study shows that cash waqf collected by IWD was still far from its potential, that amounted to Rp2,303,511,246 from Rajab 1426H to Rabiul Akhir 1428H period, which is mostly channeled to the productive sectors. Besides, the urgency of cash waqf allocation is disbursed to rehabilitation of poor family, education and culture, victims of natural disaster, health and cleanliness, and social service facility.

A study done by Isa et al (2011) compares waqf management practiced in Malaysia includes Kedah, Penang, Perak, Selangor, Johor and Wilayah Persekutuan, and outside Malaysia includes Brunei, Singapore, Indonesia, and Agama Islam Kedah. The research shows that the methods and strategies implemented in those states varied one to another. It suggests several recommendations namely involving local management such as mosque management to the waqf management, constructing national waqf management standard, developing ICT system and facility, certificating the status of land waqf, giving Trustee exposure about waqf status and purpose, and producing bond.

Norhaliza (2011) attempts to classify and order land waqf according to several aspects such as socio-economic and religious factors and locations with the desire to synchronize its importance and resources. Besides, the study uses Analytic Hierarchy Process (AHP) model to prioritize the land waqf. The research shows three major findings. Firstly, it reveals three prospective land waqf area namely Gombak, Kuala Selangor and Hulu Langat. Secondly, base on the survey, the land waqf should be developed into commercial, religious, agriculture and residential sectors in order. 
Lastly, MAIS as the waqf administrator should be balance in considering profit aspect as well as spiritual factor for developing land waqf.

\section{Methodology}

The present study extracts data both from primary and secondary sources of the literature. The former is based on the interview, while the latter are taken from published regulation and reports, journal papers, and articles. The interview with the vice head of Badan Waqf Indonesia (BWI), Ir. Muhamad Nadratuzzaman Hosen, M.Ec., Ph.D, was conducted on 19 February 2015 at Masjid Alumni, Jalan Pajajaran, Bogor, Indonesia, with the purpose to obtain direct information related to the issues faced by BWI.

The paper aims to analyze current practice of waqf management done by BWI in general. The study does not test any hypothesis. It provides general review of waqf management in Indonesia and gives some analysis on that matters. Besides, SWOT (strength, weakness, opportunities, and threat) analysis is employed to identify some unique issues faced by BWI.

The SWOT analysis is a business analys is technique that an organization can implement for each of its products, services, and markets when deciding on the best way to achieve future growth (Team FME, 2013). The process of this analysis includes classifying the strengths and weaknesses of the organization, and opportunities and threats originate from the external environment.

From this definition, strengths and weaknesses are the internal factors that support and hinder the organization in realizing its goals, while opportunities and threats are the external factors that are favorable and unfavorable for the organization in achieving its objectives. The difference between internal and external factors is the controlling power of organization. Over the former, the organization has some measure to control, while over the latter there is no ability to control from the organization.

By identifying positive and negative factors, it can be analyzed some helpful and harmful components for the organization, which results the organization's ability to synchronize its resources and capability with the external environment where the organization operates. However, SWOT is only the first step of analyzing advantages and disadvantages that the organization faces. It still needs a more complex and deeper analysis in order to extract more comprehensive conclusion.

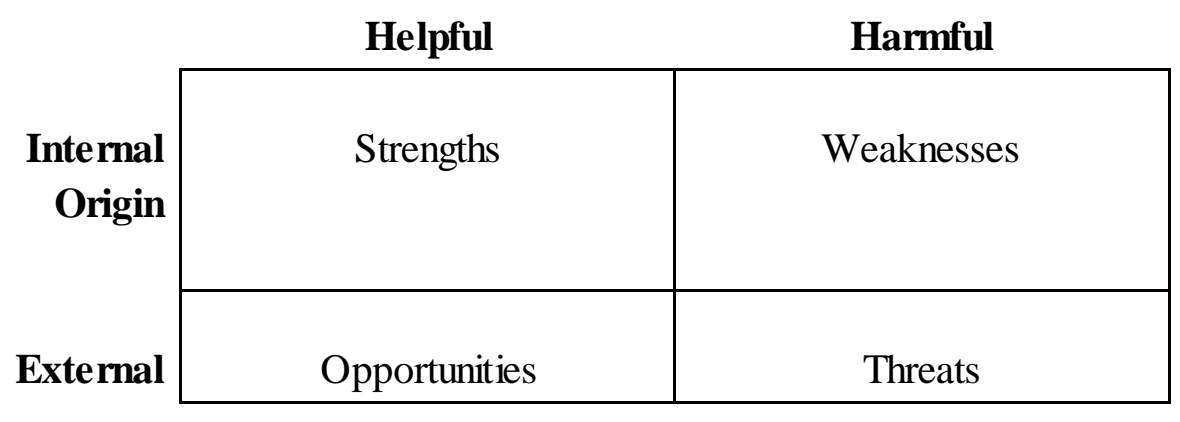




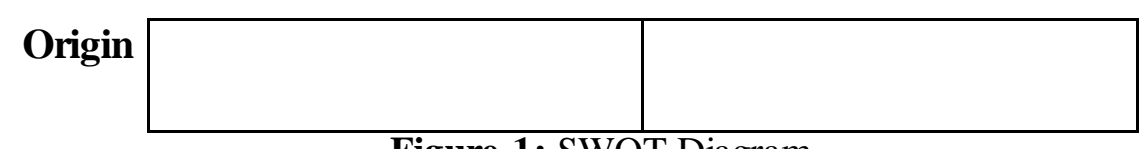

Figure 1: SWOT Diagram

\section{Result and Discussions}

\subsection{Brief History of Badan Waqf Indonesia (BWI) Establishment}

Waqf in Indonesia has been formally institutionalized in the state domain for around one decade. This is signified by the issuance Waqf Act No 412004 on 27 October 2004 by the house of the Representatives of Republic of Indonesia. This Act has initiated waqf to play more significant role in the country development process. On 15 December 2006, the government then passed regulation No 42/2006, which controls the implementation of Waqf $\mathrm{Act}^{8}$.

As the implication of this Act, Badan Waqf Indonesia (BWI) was finally established on 13 July 2006 as an independent institution, with objective to develop and improve waqf in Indonesia. In doing so, BWI has tasks to supervise and coordinate existing waqf managers, called as nazhir, to optimize their responsibilities in managing waqf asset. This expects a more productive waqf asset management that results greater socio-economic impact for the society. This establishment was based on Presidential Decree No 75/2007 and selected KH. Tholhah Hasan as the first head of BWI. BWI is mainly located in the capital city of Indonesia and has some branches in the province, city, or regency level.

For the first period, the members of BWI were selected by the President of the Republic of Indonesia with the recommendation from the Minister of Religious Affair. In the subsequent periods, the President obtained reference from the BWI selection committee. The members consist of 20 up to 30 people that represent many elements of the society with three years of tenure.

The structure of BWI comprises two main components namely Supervisory Council and Executive Body. The former has task in controlling the organization, while the latter is responsible in the operational matter of BWI. Chairman of each body is selected by the members of BWI.

On 9 June 2011, the former members were replaced by the second period of BWI members that based on the Presidential Decree No 111/M 2011. KH. Tholhah Hasan was once again elected as the head of BWI for that period. The latest period started on 19 October 2014 of which Mr. Maftuh Basyuni was selected to replace KH. Tholhah Hasan according to the Presidential Decree No 177/M 2014. During these three periods, BWI has been focusing more on the development of waqf regulation infrastructure.

\footnotetext{
${ }^{8}$ Retrieved from http//bwi.or.id/index.php/in/tentang-bwi/sekilas-bwi
} 


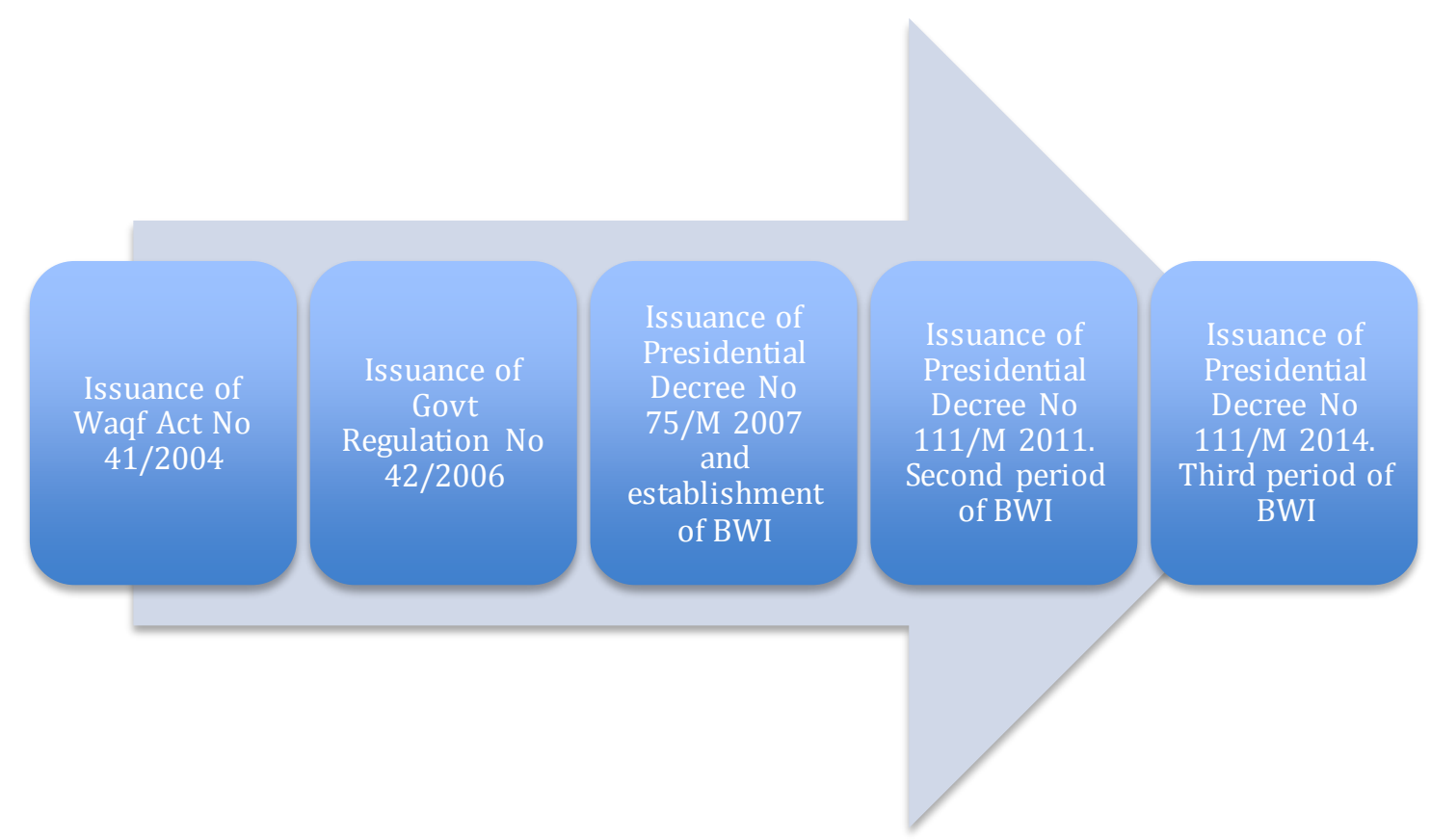

Figure 2. Timeline of Badan Waqf Indonesia

\subsection{Vision and Mission of Badan Waqf Indonesia}

According to the Waqf Act No 41/2004, the vision of Badan Waqf Indonesia is to realize an independent and trusted institution that has ability and integrity to develop both national and international waqf. The mission of the board is to become a professional institution that develop waqf potential and its economic advantages for the sake of the worship to God (ibadah) as well as society empowerment.

\subsection{Duties and Authorities of Badan Waqf Indonesia}

According to Waqf Act No 41/2004 article 49 clause 1, duties and authorities of BWI are as below:

a. To guide nazhir in managing and developing waqf asset.

b. To manage national and international waqf asset.

c. To give authorization of the changes of waqf status or the changes of the benefit allocation of waqf asset.

d. To terminate or change nazhir if necessary.

e. To give agreement on the exchange of waqf asset.

f. To give advise or recommendation to the Government for the waqf policy making process.

Specifically, the regulation of BWI No 1/2007 states the details of duties and authorities of BWI are as follows:

a. To guide nazhir in managing and developing waqf asset.

b. To construct a guidance of waqf asset management and development.

c. To manage and develop national and international waqf asset and neglected waqf asset. 
d. To give authorization of the changes of waqf status or the changes of the benefit allocation of waqf asset.

e. To give agreement on the exchange of waqf asset.

f. To give advise or recommendation to the Government for the waqf policy making process.

g. To evaluate the performance of nazhir, to publish application form for nazhir, and reselect nazhir.

h. To terminate or change nazhir if necessary.

i. To give advise or recommendation to the Minister of Religious Affair in selecting Islamic finance institution as the recipient of cash waqf.

j. To receive the application of 'Akta Ikrar Waqf' of moving objects from the officer of 'Akta Ikrar Waqf' publisher.

\subsection{Potential and Realization of Waqf Assets and Fund in Indonesia}

As the Moslem majority country, Indonesia has a huge potential in the number of land and cash waqf. In terms of land waqf, there are 2,171,041,349.74-meter square of waqf land area, which spread in 414,848 locations across the country (Ministry of Religious Affair of Republic of Indonesia Report, 2010). Unfortunately, only 5 percent of the land has been well managed for productive sector, while remaining 95 percent has not been optimally occupied yet.

The potential of cash waqf is also very promising. According to Nasution (2006) as cited in Nafis (2012), there are 10 million generous Moslem in Indonesia with average income lay between Rp500 thousands to Rp10 million per months. With that number, at least Rp3 trillion per year can be collected from cash waqf. Unfortunately, the realization of cash waqf is still far from its expectation (Affandi and Nufus, 2010).

In Indonesia, cash waqf has become a massive action since 8 January 2010 when the former President of Republic of Indonesia, Prof. Dr. Susilo Bambang Yudhoyono, inaugurated cash waqf national movement in the presidential palace. Since that initiation, there have been 15 Islamic financial institutions ${ }^{9}$ and 100 Shariah Financial Services Cooperatives ${ }^{10}$ that receive cash waqf from the public. Nonetheless, only 7 Islamic financial institutions and 6 Shariah Financial Services Cooperatives report the collection of cash waqf to BWI.

\footnotetext{
${ }^{9}$ Muamalat Indonesia Bank, Shariah Mandiri Bank, Shariah BNI Bank, Shariah Mega Bank, Shariah DKI Bank, Shariah BTN Bank, Shariah Bukopin Bank, BPD Yogya Shariah, BPD Kalbar Shariah, BPD Jateng Shariah, BPD Kepri Riau Shariah, BPD Jatim Shariah, BPD Sumut Shariah, Shariah CIMB Niaga Bank, and Shariah Panin Bank.

${ }^{10}$ Some of them are Badan Waqf Sultan Agung Foundation Middle Java, Nahdlatul Ulama Jakarta, Haji Sepanjang Hayat Foundation Jakarta, Pondok Indah Waqf Foundation Depok, Baitul Mal Muamalat (BMM) Jakarta, Waqf Al-Azhar Jakarta, Rumah Waqf Indonesia West Java, Bina Nurul Fikri Jakarta, Waqf Bangun Nurani Bangsa (ESQ) Yatim Mandiri East Java, Pos Keadilan Peduli Umat Jakarta, Griya Yatim and Du'afa Banten, Waqf Pro 99 West Java, Global Waqf ACT Jakarta, Dompet Dhuafa TWI, etc.
} 
Table 1 presents the total cash waqf collection from 7 Islamic financial institutions. From Table 1, it can be concluded that the total cash waqf collected by Islamic financial institutions per 31 December 2014 was Rp4,115,823,569. Shariah Mandiri Bank, as the largest Islamic bank in Indonesia, contributed more than 50 percent of the total cash waqf collection. Moreover, Shariah BNI added the second largest contribution of 17 percent, while Mualamat Indonesia Bank, Shariah DKI Bank, and Shariah Mega Bank gave 10, 8, and 7 percent of contribution respectively. Lastly, Shariah Bukopin Bank and Shariah BTN equally contributed the remaining 2 percent.

Table 2 informs the cash waqf collection from 6 Shariah Financial Services Cooperatives. Per December 2014, the total number of cash waqf collection amounted to $\mathrm{Rp} 224,337,079$. The largest collection from January to September 2014 was contributed by Al-Huda Cooperative (Rp69,718,500), followed by L-Risma Cooperative (Rp19,103,100) and Melati Cooperative (Rp10,000,000). During January to August 2014, BMT An-Najah and Tamzis Baituttamwil have contributed Rp17,328,000 and Rp24,224,000 respectively to the total collection. Lastly, Marhamah Cooperative has given Rp83,963,479 since July 2011 up to July 2014. These six institutions are formally listed cash waqf recepients.

The procedures of cash waqf flow from waqf donator (wakif) to waqf beneficiary (mauquf alaih) are as follows. Wakif can go to an Islamic finance institution (IFI), which is a formal cash waqf recipient, in order to fulfill and sign Akta Ikrar Waqf (AIW). After that, the IFI issues cash waqf certificate, called as SWU, and give it to Wakif. Subsequently, Wakif transfer some amount of money to the nazhir bank account to be managed. The return of the cash waqf deposit is then disbursed to the mauqufalaih (Bahan Data BWI, 2015).

In terms of distribution, the return on cash waqf investment is allocated to several sectors including education. The aids are in form of school renovations, Indonesian-Arabic dictionaries disbursement, and tuition fee assistantship for poor and needy children. Currently, BWI has been mostly focusing to help hospital construction for Mother and Children in Serang, Banten Province (Badan Waqf Indonesia Data, 2015).

Table 1: The Collection of Cash Waqf from Islamic Financial Institutions (IFIs) per 31

December 2014

\begin{tabular}{|l|c|c|c|c|c|}
\hline \multicolumn{1}{|c|}{$\begin{array}{c}\text { Name of } \\
\text { IFIs }\end{array}$} & $\begin{array}{c}\text { Balance up } \\
\text { to 31 } \\
\text { December } \\
\mathbf{2 0 1 4}(\mathbf{R p})\end{array}$ & $\begin{array}{c}\text { Credit } \\
\mathbf{2 0 1 4}(\mathbf{R p})\end{array}$ & $\begin{array}{c}\text { Debit } \\
\mathbf{2 0 1 4}(\mathbf{R p})\end{array}$ & $\begin{array}{c}\text { Balance up } \\
\text { to 31 } \\
\text { December } \\
\mathbf{2 0 1 4}(\mathbf{R p})\end{array}$ & $\begin{array}{c}\text { Percentage } \\
\text { of } \\
\text { Contribution } \\
\mathbf{( \% )}\end{array}$ \\
\hline $\begin{array}{l}\text { Muamalat } \\
\text { Indonesia } \\
\text { Bank }\end{array}$ & $389,874,114$ & $8,000,000$ & & $397,874,114$ & 10 \\
\hline $\begin{array}{l}\text { Shariah } \\
\text { Mandiri Bank }\end{array}$ & $2,497,743,014$ & $72,661,841$ & $265,000,000$ & $2,305,404,855$ & 56 \\
\hline
\end{tabular}


AL-INFAQ: Jurnal Ekonomi Islam, (ISSN: 2087-2178, e-ISSN: 2579-6453)

Vol. 8 No. 2, December 2017

\begin{tabular}{|l|r|r|r|r|c|}
\hline Shariah BNI & $559,163,708$ & $160,080,000$ & & $719,243,708$ & 17 \\
\hline $\begin{array}{l}\text { Shariah DKI } \\
\text { Bank }\end{array}$ & $326,826,595$ & $14,287,686$ & & $341,114,281$ & 8 \\
\hline $\begin{array}{l}\text { Shariah Mega } \\
\text { Bank }\end{array}$ & $251,090,063$ & $25,481,300$ & & $276,571,363$ & 7 \\
\hline $\begin{array}{l}\text { Shariah } \\
\text { Bukopin Bank }\end{array}$ & $41,433,259$ & $6,225,000$ & & $47,658,259$ & 1 \\
\hline Shariah BTN & $27,056,984$ & 900,006 & & $27,956,990$ & 1 \\
\hline Total & $\mathbf{4 , 0 9 3 , 1 8 7 , 7 3 6}$ & $\mathbf{2 8 7 , 6 3 5 , 8 3 2}$ & $\mathbf{2 6 5 , 0 0 0 , 0 0 0}$ & $\mathbf{4 , 1 1 5 , 8 2 3 , 5 6 9}$ & $\mathbf{1 0 0}$ \\
\hline
\end{tabular}

Table 2: The Collection of Cash Waqf from Shariah Financial Services Cooperatives (SFSCs) per 31 December 2014

\begin{tabular}{|c|c|c|c|}
\hline Name of SFSCs & Status & $\begin{array}{c}\text { Amount of } \\
\text { Cash Waqf } \\
\quad(\mathrm{Rp})\end{array}$ & Description \\
\hline BMT An Najah & Listed in BWI & $17,328,000$ & January - August 2014 \\
\hline$\overline{\text { Tamzis Baituttamwil }}$ & Listed in BWI & $24,224,000$ & January - August 2014 \\
\hline L-Risma & Listed in BWI & $19,103,100$ & January - September 2014 \\
\hline Al-Huda & Listed in BWI & $69,718,500$ & January - September 2014 \\
\hline Marhamah & Listed in BWI & $83,963,479$ & July 2011 - July 2014 \\
\hline Melati & Listed in BWI & $10,000,000$ & January - September 2014 \\
\hline & Total & $224,337,079$ & \\
\hline
\end{tabular}

\subsection{SWOT Analysis}

\section{Strengths}

In accordance with the Waqf Act No 41/2004, although the President of Republic of Indonesia has the right to appoint and terminate Badan Waqf Indonesia's (BWI) membership, the institution is independent in performing its role. This independent status is definitely a favorable factor for BWI to prevent any interest collides while executing its duties. Nevertheless, BWI has to still regard the recommendation and consideration from Indonesian Council of Ulama (Majelis Ulama Indonesia) and the Ministry of Religious Affair.

Moreover, BWI has tied a good cooperation with other interrelated institutions in doing its authorities. Not only with the Indonesian Council of Ulama (Majelis Ulama Indonesia) and Ministry of Religious Affair, BWI has also had collaboration with National Land Agency, National Development Planning Agency, Central Bank of Indonesia, Islamic Development Bank, and other institutions. Besides, it is also possible for BWI to have partnership with the investors in order to develop waqf asset to become more productive.

\section{Weaknesses}

The dualism between BWI and Waqf Directorate of Ministry of Religious Affair has caused some confusion in the area of national waqf coordinator roles. Both BWI and Waqf Directorate of Ministry of Religious Affair have duties to guide and control 
nazhir and administer waqf properties applications and publicly announce it. As a consequence, the mix- up position of the two institutions is inevitable. Besides, both institutions have fund from the government but with an unequal amount.

Moreover, the internal unfavorable factor results from the lack of integration between BWI and other waqf institutions. There are many waqf institutions including private sector that do not regularly report their performances in terms of the collection as well as the management and disbursement to BWI as the national coordinator of waqf management. According to Waqf Act No 41/2004, nazhir has the responsibility to report its operational activities to BWI. Likewise, there even exist waqf institutions that have not been given any operating licenses from BWI. However, the current regulations have not managed the punishment of such cases.

\section{Opportunities}

As mentioned earlier, Indonesia is the most populous Moslem country in the world. With Moslem majority of 237 million people (Statistic Center Board, 2010), this huge number is a great external favorable factor that supports waqf development in Indonesia. Besides, the nature of the establishment of Islamic institutions in Indonesia such as Islamic banks and insurances, majority is based on the initiations from the society. For instance, Ikatan Cendekiawan Muslim Indonesia (ICMI) commenced the launching of Muamalat Indonesia Bank in 1992 as the very first Islamic commercial bank in Indonesia. As a result, this movement had inspired the government to launch the first regulation related to Islamic bank in Indonesia seven years later. This bottomup style of approach is a good opportunity for BWI to develop waqf as a massive movement.

With the great number of Moslem people, comes the great potential on waqf cash and land. According to Ministry of Religious Affair of Republic of Indonesia Report (2010), as mentioned earlier, the number of land waqf is very promising. There are 414,848 locations of land waqf with land area of 2,171,041,349.74-meter square. However, 95 percent of it has not been optimally managed yet.

In terms of cash waqf, Nafis (2012) assumed if Rp100 thousand can be collected from 20 million Moslem per month, there would be Rp24 trillions of cash waqf that can be used for the sake of ummah. It can be imagined how useful it would be for poverty mitigation, economic empowerment, ummah independence achievement, and many more.

\section{Threats}

Although Indonesia has potential of its Moslem majority, there has been lack of awareness and knowledge of people towards waqf. People recognize waqf is limited only to land, mosques, and graveyard. Therefore, such cash waqf and its derivatives have not been acknowledged and hence its development is quite stagnant as compared to its potential. 
Furthermore, the most problematic aspect that has been faced stems from waqf managers (nazhir) part, which can be individual, organization, or corporation. There are many waqf managers that are lack in knowledge and competencies on waqf. Their activities are limited to only maintain the lands, without having any vision and ability to develop the land becomes more productive. On the other words, the current image of nazhir portrays its responsibility only to take care of the lands, which results the absence of future plan on the land improvement. This might be caused by the current position as nazhir is only inherited from the parents and the previous generation. Therefore they just take the roles for granted and do not fully understand what their functions are.

Not only from nazhir, the threats also occurs on waqf land status. Majority of the lands have not been certified yet and hence the lands are taken by other parties. For instance, in Semarang, Middle Java Province, the initial of waqf land area was 140 hectares and now is only 35 hectares left, due to the absence of waqf land certification. Besides, over 1 million hectares of waqf land of Muhammadiyyah organization, only 10 percent of it has been certified.

Furthermore, the waqf land area in the middle of city has hugely decreased from time to time, and being moved to some rural areas. According to shariah law, the changed location of waqf law from one to another is actually allowed as long as the wide-scale remains, and called as 'gislah'. However, the problem emerges when the movement of the land does not consider any religious and socio-economic aspects. For example, there are some mosques of waqf land in Jakarta that were moved to Sukabumi for the purpose of business activities. Although the physical traits remained the same, but the Islamic landscape and its syiar impact disappeared in the big city.

In terms of mosques as waqf assets, since December 2014, the national fatwa commission has agreed that the lands where the mosque is built must become waqf land. As the consequence, the building is considered as mosque only if the land is from waqf. This definitely has become a very big challenge, as many mosques in Indonesia were not built in the waqf land, such as Istiqlal Mosque in Jakarta, which was built in the land that belongs to the state. In this case, the certification issue has again become very essential.

Another threat arises from cash waqf, which people has not widely recognized. Due to its capital perpetuation requirement, currently, most of cash waqf is only deposited in the Islamic banks. According to the national fatwa commission (2001/2002), cash waqf can be in the form of stocks and investment as long as the capital is preserved. However, many Islamic banks in Indonesia have not been interest to develop this waqf because it is difficult to make cash waqf as investment products. Moreover, the existing regulations have not really supported on the cash waqf development. 


\begin{tabular}{|c|c|c|}
\hline & Helpful & Harmful \\
\hline $\begin{array}{r}\text { Internal } \\
\text { Origin }\end{array}$ & $\begin{array}{l}\quad \text { Strengths } \\
\text { 1. Independent status of BWI } \\
\text { 2. Good cooperation with } \\
\text { other interrelated } \\
\text { institutions }\end{array}$ & $\begin{array}{l}\text { Weaknesses } \\
\text { 1. Dualism between BWI } \\
\text { and Waqf Directorate of } \\
\text { Ministry of Religious } \\
\text { Affair } \\
\text { 2. Lack of integration } \\
\text { between BWI and other } \\
\text { waqf institutions. }\end{array}$ \\
\hline $\begin{array}{r}\text { External } \\
\text { Origin }\end{array}$ & $\begin{array}{l}\text { Opportunities } \\
\text { 1. The amount of Moslem in } \\
\text { Indonesia } \\
\text { 2. Great potential of waqf cash } \\
\text { and land }\end{array}$ & $\begin{array}{l}\text { Threats } \\
\text { 1. Lack of awareness and } \\
\text { knowledge of Moslem in } \\
\text { Indonesia towards waqf } \\
\text { 2. Problem of waqf managers } \\
\text { (nazhir): biggest challenge } \\
\text { 3. Problem of waqf land } \\
\text { status } \\
\text { 4. Problem of the change of } \\
\text { waqf land location } \\
\text { 5. Controversy of cash waqf }\end{array}$ \\
\hline
\end{tabular}

Figure 3: SWOT Diagram of Badan Waqf Indonesia (BWI)

\section{Conclusions and Recommendations}

\subsection{Conclusions}

The current research aims to achieve two main objectives. Firstly, it attempts to present the performance of waqf management in Indonesia, by taking case Badan Waqf Indonesia (BWI), as an independent coordinator of national waqf management. The study shows that the huge potential of land and cash waqf unfortunately has not been followed by its realization. In terms of land waqf, only 5 percent of the total land area has been optimally managed. As for cash waqf, the collection per December 2014 has only accomplished around 10 percent of its potential.

Secondly, the paper examines some unique issues faced by BWI using SWOT (strengths, weaknesses, opportunities, and threats) analysis. This tool is useful in order to investigate some helpful and harmful factor coming from both internal and external organization. The independent status of BWI and good cooperation with other interrelated institutions like Indonesian Ulama Council and Ministry of 
Religious Affair are the two internal factors that support BWI in executing its role. On the other hand, there still occur some weaknesses at many sides, which hamper BWI to realize its objectives. The problem emerges on dualism phenomenon between BWI and Waqf Directorate of Ministry of Religious Affair in performing coordinator role of waqf management in Indonesia. Moreover, lack of integration between BWI and other waqf institutions has become an internal unfavorable factor.

In terms of the opportunities, BWI benefits from the huge population of Indonesian Moslem, which results great potential of waqf cash and land. Unfortunately, this potential amount comes together with the lack of awareness and knowledge of people towards waqf. Moreover, there have been some problems on waqf managers (nazhir) as the major challange. Besides, problem of waqf land status, problem of the change of waqf land location, and controversy of cash waqf are also other threats that BWI has faced.

\subsection{Recommendations}

The study suggests there are several recommendations to be drawn from the findings. These are expected to give valuable input for the betterment of Badan Waqf Indonesia (BWI) in the future.

Firstly, as nazhir play a crucial position in the process of waqf development process, it is important to educate them so that they have sufficient knowledge and competency as nazhir. BWI can conduct a continuous education program for nazhir with the desire to realize capable nazhir in performing their roles.

Secondly, the certifications of land waqf urge to conduct in order to clarify the status of the lands that prevent other parties to take over it. This needs competent notaries that understand well about waqf. Therefore, BWI should have collaboration with other related institutions as well as Government to prepare some qualified notaries, because this needs funding that state has to provide.

Thirdly, when it comes to land waqf location movement, it should consider other aspects include religious missions and socio-economic factors. As a result, waqf can fully give positive impact to the society.

Fourthly, as the coordinator of national waqf management, BWI has the right to receive reports from other private waqf institutions. Therefore, these institutions are required to frequently report their performances to BWI, which can result more comprehensive and complete national waqf data. This can be effectively implemented if there is supportive regulation that manages legal punishment for the disobedience.

Fifthly, there is a need to create better cooperation and collaboration between BWI and the Directorate of Waqf of Ministry of Religious Affair to relieve the dualism functions. This can be done by appointing the members of Directorate of Waqf of Ministry of Religious Affair to be part of BWI members. As a consequence, the roles of both institutions can be more integrative and encouraging one to another.

Lastly, there is a need to deliver a comprehensive education to people about waqf to give clear understanding of the concept that aims to increase people's 
knowledge and awareness about waqf. Moreover, a creative promotion can also be done in order to introduce waqf to the public. These methods shall help BWI in creating waqf as national mass movement.

\section{References}

Affandi, A. and Nuffus, D.N. (2010). Analysis on Cash Waqf Return Fund Allocation in Indonesia: A Case Study in Indonesian Waqf Deposit. [Proceeding]. Seventh International Conference - The Tawhidi Epistemology: Zakat and Waqf Economy, Bangi 2010

Badan Waqf Indonesia Data. (2015).

Badan Waqf Indonesia Regulation No 1/2007

Badan Waqf Indonesia Regulation No 1/2009

Ihsan, H. (2007). An Explanatory Study of Waqf Accounting and Management in Indonesian Waqf Institutions: The Cases of Dompet Dhuafa and UII Waqf Foundations. [Dissertation]. Kuala Lumpur: International Islamic University Malaysia.

Ihsan, H. and Adnan, M.A. (2010). Waqf Accounting and the Construction of Accountability. Retrieved from http://www.iefpedia.com/english/?p=4484

Isa, Z.M., Ali, N., and Harun, R. (2011). A Comparative Study on Waqf Management in Malaysia. 2011 International Conference on Sociality and Economics Development IPEDR, vol.10. IACSIT Press, Singapore.

Kahf, M. (2002). Waqf and Its Sociopolitical Aspects. Retrieved from http://monzer.kahf.com/papers/english/WAQF_and_its_Sociopolitical_Aspect $\underline{\text { s.pdf }}$

Ministry of Religious Affair of Republic of Indonesia Report. (2010).

Nafis, M.C. (2012). Aplikasi Wakaf Uang di Indonesia. Retrieved from http://b wi.or.id/index.php/in/publikasi/artikel/974-aplikasi-wakaf-uang-diindonesia

Norhaliza. (2011). Categorization and Prioritization of Waqf Lands based on Sectors, Strategic Locations, Socio-Economic and Religious Factors: The Case of Selangor. [Thesis]. Kuala Lumpur: International Islamic University Malaysia.

Rashid, S.K. (2014). Factors Affecting the Development and Good Governance of Awqaf. [Proceeding]. International Conference on Waqf Management: Turkish Experience, 18-20 June 2014. Retrieved from http://iimu.org/waqf/presentation/factors-affecting-the-contemporary-revivaland-management-of-awqaf/

Statistic Center Board. (2010).

Team FME. (2013). SWOT Analysis Strategy Skills. Retrieved from http://www. freemanagement-ebooks.com/dldebk-pdf/fme-swot-analysis.pdf

Waqf Act No 41/2004

Zaki, A.A.L., Norzaidi, M.D., \& Che Zuina, I. (2008). Pengurusan Harta Wakaf dan Potensinya ke Arah Kemajuan Pendidikan Umat Islam di Malaysia. Jurnal Pengurusan JAWHAR. 